\title{
Idiopathic hyperkeratosis of the nipple and areola: A report of two cases
}

\author{
Meme bașı ve areolanın idiyopatik hiperkeratozu: Iki olgu sunumu
}

๑ Gülhan Gürel, ๑ Sevinç Șahin*, ๑ Emine Çölgeçen

Bozok University Faculty of Medicine, Department of Dermatology, ${ }^{*}$ Department of Pathology, Yozgat, Turkey

\begin{abstract}
Hyperkeratosis of the nipple and areola, a rarely seen benign dermatosis, is characterized by a verrucous appearance of the nipple and the areola. Females constitute the majority of the cases, however, there are also rare reports of male cases. On clinical examination, hyperkeratotic and hyperpigmented plaques are located on the nipple and/or areola. No erythema or induration is observed on the affected skin. According to a widely adopted classification system, primary hyperkeratosis of the nipple and areola is divided into three groups as type 1 which is coincidentally associated with keratinization disorders such as ichthyosis and Darier's disease; type 2 which is associated with hormonal factors or systemic diseases; and type 3 which is entirely considered an idiopathic form. Idiopathic form often affects female patients in the second or third decade of life and occurs spontaneously. Patients often present due to cosmetic reasons. The etiology of this condition has not been fully elucidated and, to date, various treatment methods have been attempted. Herein, we report two female cases (25-year-old and 14-year-old) of idiopathic hyperkeratosis of the nipple and areola based on the clinical and histopathological examination.
\end{abstract}

Keywords: Nipple, hyperkeratosis, areola

Öz

Meme başı ve areolanın hiperkeratozu, meme başı ve areolanın verrüköz görünüm alması ile karakterize, oldukça nadir rastlanan selim seyirli bir dermatozdur. Hastaların önemli bir kısmını kadın cinsiyet oluşturmasına rağmen nadir de olsa erkek olgular bildirilmiştir. Klinik olarak meme başı ve/veya areolada hiperkeratotik, hiperpigmente plaklar görülür. Tutulan deride eritem ve indurasyon bulunmaz. Son yוllarda en çok kabul gören sınıflandırmaya göre meme başı ve areolanın primer hiperkeratozu olarak gruplandırılan ve rastlantısal olarak iktiyozis ve Darier hastalığı gibi keratinizasyon bozuklukları ile ilişkili olan varyant tip 1, hormonal faktörler ya da sistemik hastalıklarla ilişkili varyant tip 2, tamamen idiyopatik olan form ise tip 3 olarak gruplandırımışır. Bu idiyopatik tip genellikle ikinci ya da üçüncü dekaddaki kadın olguları etkiler ve spontan olarak ortaya çıkar Hastalar genellikle kozmetik nedenlerden dolayı hekime başvururlar. Etiyolojisi tam olarak aydınlatılamamış olan bu hastalığın tedavisinde çok çeşitli yöntemler kullanılmışır. Biz burada klinik ve histopatolojik olarak meme başı ve areolanın idiyopatik hiperkeratozu tanısı koyduğumuz 25 yaşındaki ve 14 yaşındaki iki kadın olguyu sunmaktayız.

Anahtar Kelimeler: Meme başı, hiperkeratoz, areola

\section{Introduction}

Hyperkeratosis of the nipple and areola, a rarely seen benign dermatosis, is characterized by a verrucous appearance of the nipple and the areola. Since there is a very limited number of cases reported in the literature, the etiology of the disease, associated diseases, disease course, and treatment still remain to be elucidated. Verrucous plaques often seen in females as unilateral or bilateral lesions affecting the nipple and/or areola are typical findings of this dermatosis ${ }^{1,2}$. Herein, due to the rare occurrence of this condition, we report two cases of idiopathic hyperkeratosis of the nipple and areola diagnosed based on the clinical and histopathological findings.

Address for Correspondence/Yazışma Adresi: Gülhan Gürel MD, Bozok University Faculty of Medicine, Department of Dermatology, Yozgat, Turkey Phone: +90 5069260596 E-mail: gulhanozturkgure|@hotmail.com Received/Geliş Tarihi: 22.05.2017 Accepted/Kabul Tarihi: 28.11.2017 ORCID ID: orcid.org/0000-0001-5716-8750 


\section{Case Reports}

\section{Case 1}

A 25-year-old female patient presented to our outpatient clinics with the complaint of dark brown crusting on the nipples for the past seven years. Her medical history was not remarkable for any disease or medication use. Her family history was also not remarkable. Physical examination did not show any pathological finding. Dermatological examination revealed bilateral dark brown, hyperpigmented verrucous lesions on the nipples (Figure 1a). Routine laboratory test results were within the normal ranges. A punch biopsy was performed to the lesion on the left nipple. Light microscopic examination revealed fragmented keratin layers with a "basket-woven" appearance characterized by orthokeratotic hyperkeratosis (Figure 1b), irregular acanthosis characterized by elongation and fusion of rete ridges in the epidermis, increased melanin in the basement membrane and mild exocytosis of lymphocytes and minimal perivascular lymphocytic infiltration in the dermis (Figure 1c).

Based on the available clinical and histopathological findings, the patient was diagnosed with hyperkeratosis of the nipple and areola and placed on a treatment with topical calcipotriol and topical mometasone furoate twice daily. However, the patient showed no response to the treatment.

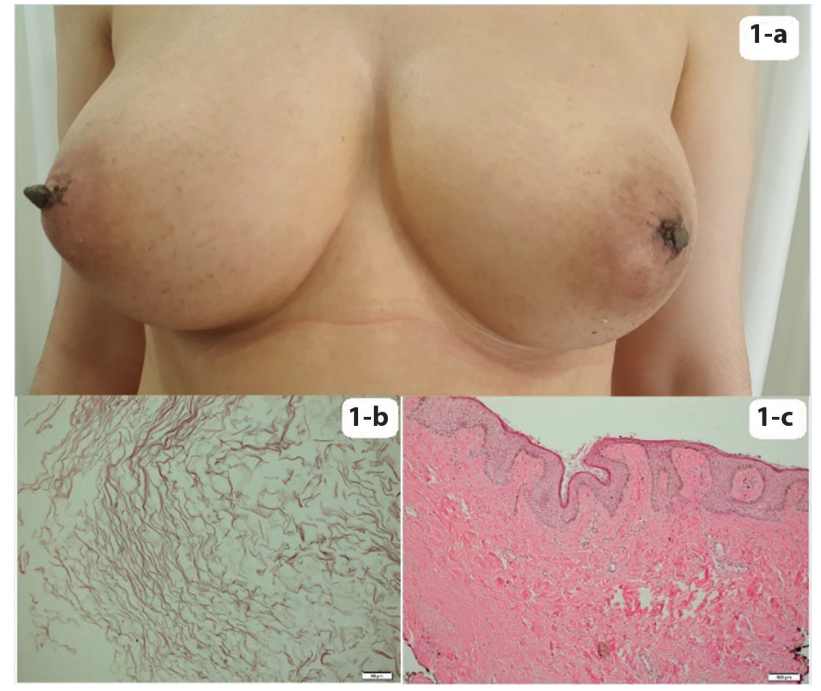

Figure 1. a) Bilateral dark brown, pigmented verrucous lesions on the nipples. b) Orthokeratotic keratin layer with fragmented appearance detached from the lesion surface, (hematoxylin and eosin staining, $\times 200$ ). c) Microscopic appearance of punch biopsy showing irregular acanthosis in the epidermis and increased melanin in the basement membrane, (hematoxylin and eosin staining, x100)

\section{Case 2}

A 14-year-old female patient presented to our outpatient clinic with the complaint of bilateral discoloration of the nipples in the past two years. Her medical history was not remarkable for any disease or medication use. Her family history was also not remarkable. Physical examination did not reveal any pathological finding. Dermatological examination revealed bilateral hyperkeratotic brown lesions around the nipple (Figure 2a). Routine laboratory test results were within the normal ranges. A punch biopsy was performed to the lesion in the right nipple. Light microscopic examination revealed orthokeratotic hyperkeratosis with a superficial "basket-woven" appearance, irregular acanthosis characterized by elongation and fusion of rete ridges in the epidermis, increased melanin in the basement membrane, mild exocytosis of lymphocytes, and minimal perivascular lymphoid infiltration in the dermis (Figure 2b, 2c).

Based on the available clinical and histopathological findings, the patient was diagnosed with hyperkeratosis of the nipple and areola and was placed on a treatment with topical calcipotriol and topical mometasone furoate twice daily. However, the patient only partially responded to the treatment.

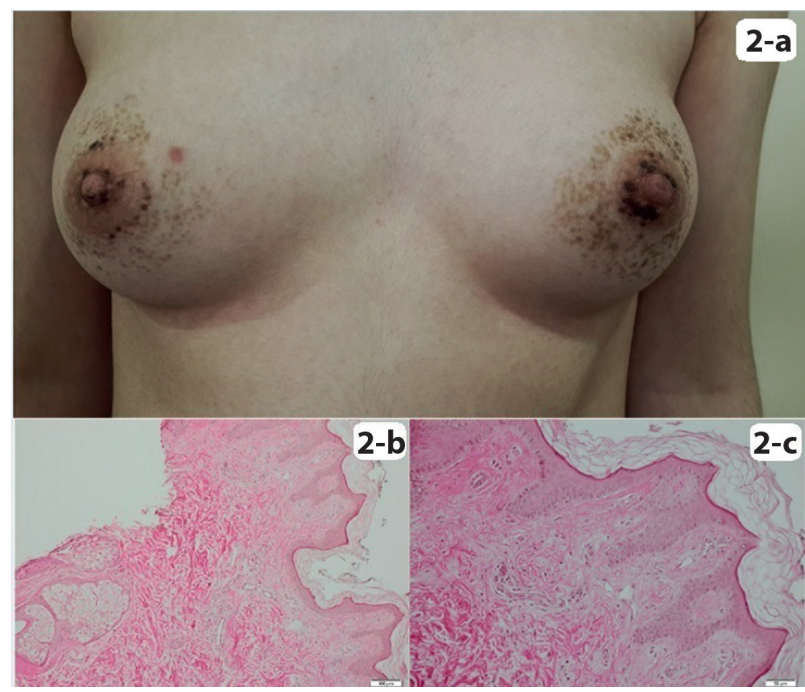

Figure 2. a) Bilateral hyperkeratotic brown lesions around the areola. b, c) Microscopic appearance of punch biopsy showing "basketwoven" orthokeratosis, mild irregular acanthosis in the epidermis, and increased melanin in the basement membrane, (hematoxylin and eosin staining, $x 100$ and $\times 200$, respectively)

\section{Discussion}

Hyperkeratosis of the nipple and areola, which is also termed nevoid/ primary hyperkeratosis of the nipple and areola, was first described in $1923^{3}$. Levy-Franckel divided this entity into three categories: 1) Lesion occurring with the expansion of the epidermal nevus; 2) Lesion associated with acanthosis nigricans, Darier's disease, ichthyosis, cutaneous T-cell lymphoma, or chronic eczema; and 3) The idiopathic form also named isolated nevoid type ${ }^{3}$. According to the classification system proposed by Mehanna et al. ${ }^{2}$ which has been widely adopted in recent years, primary hyperkeratosis of the nipple and areola is divided into three groups as type 3 which is coincidentally associated with keratinization disorders such as ichthyosis and Darier's disease, type 1 which is associated with hormonal factors or systemic diseases, and type 2 which is entirely considered an idiopathic form. The idiopathic form often affects females in the second and third decade of life and occurs spontaneously². In our both cases, there was no previous history of a lesion on the nipple. Dermatological examination showed no evidence of lesions, which could be associated with ichthyosis, acanthosis nigricans, Darier's disease, and other conditions. Although 
histopathologic features may mimic epidermal nevus or acanthosis nigricans, hyperkeratosis of the nipple and areola is a lesion acquired after puberty. Seborrheic keratosis presents as sharply demarcated papules or plaques, whereas nevoid hyperkeratosis of the nipple or areola presents as a plaque diffusely involving the nipple or the areola ${ }^{3}$. Therefore, both cases were diagnosed with idiopathic hyperkeratosis.

Although hyperkeratosis of the nipple and areola affects both females and males, female cases account for $80 \%$ of the cases ${ }^{4}$. On clinical examination, hyperkeratotic and hyperpigmented plaques are located on the nipple and/or areola. No erythema or induration is observed on the affected skin $^{4}$. Patients often present due to cosmetic concerns ${ }^{5}$. Our first case had no obvious symptoms other than occasional itching. However, both patients complained of cosmetic problems associated with the lesions.

Clinical appearance is often sufficient to establish a diagnosis; however, skin biopsy must be performed for the definitive diagnosis. Histopathological examination is useful in the differentiation of orthokeratotic hyperkeratosis, mild acanthosis, and papillomatosis ${ }^{3,6}$. Various treatment methods have been attempted for the treatment of hyperkeratosis of the nipple and areola. These include topical corticosteroids, topical vitamin D analogues, topical retinoic acid derivatives, radio-frequency ablation, cryotherapy, and carbon dioxide laser $^{7-10}$. The disease frequently recurs ${ }^{1}$. In our cases, we used topical mometasone furoate and topical calcipotriol. The first case did not respond to the treatment, however, the second case partially responded.

These two cases of idiopathic hyperkeratosis of the nipple and areola diagnosed based on the clinical and histopathological findings were deemed worthy of presentation due to rare occurrence of this condition.

\section{Ethics}

Informed Consent: Informed consent form was obtained from the patients.

Peer-review: External and internal peer-reviewed.

\section{Authorship Contributions}

Surgical and Medical Practices: G.G., Concept: G.G., E.Ç., Design: G.G., S.Ş., E.Ç., Data Collection or Processing: G.G., S.Ş., Analysis or Interpretation: G.G., S.Ş., Literature Search: G.G., E.Ç., Writing: G.G., S.Ş., E.Ç.

Conflict of Interest: The authors declare no conflict of interest.

Financial Disclosure: The authors declared that this study received no financial support.

\section{References}

1. Peker D, Ferahbaș A, Borlu M, Utaş S, Kontaş O: Topikal kalsipotriol tedavisinin etkili olduğu nevoid hiperkeratoz olgusu. Turkderm 2005;39:1303.

2. Mehanna A, Malak JA, Kibbi AG: Hyperkeratosis of the nipple and areola: report of 3 cases. Arch Dermatol 2001;137:1327-8.

3. Baykal C, Büyükbabani N, Kavak A, Alper M: Nevoid hyperkeratosis of the nipple and areola: a distinct entity. J Am Acad Dermatol 2002;46:414-8.

4. Krishnan RS, Angel TA, Roark TR, Hsu S. Nevoid hyperkeratosis of the nipple and/or areola: a report of two cases and a review of the literature. Int J Dermatol 2002;41:775-7.

5. Chikhalkar SB, Misri R, Kharkar V: Nevoid hyperkeratosis of nipple: nevoid or hormonal? Indian J Dermatol Venereol Leprol 2006;72:384-6.

6. Shastry V, Betkerur J, Kushalappa PA: Unilateral nevoid hyperkeratosis of the nipple: a report of two cases. Indian J Dermatol Venereol Leprol 2006;72:303-5.

7. Ghanadan A, Balighi K, Khezri S, Kamyabhesari K: Nevoid Hyperkeratosis of the Nipple and/or Areola: Treatment with Topical Steroid. Indian J Dermatol 2013;58:408.

8. Bayramgürler D, Bilen N, Apaydin R, Erçin C. Nevoid hyperkeratosis of the nipple and areola: treatment of two patients with topical calcipotriol. J Am Acad Dermatol 2002;46:131-3.

9. Guevara-Gutiérrez E, Tarango-Martínez VM, Sandoval-Tress C, HernándezTorres M. Unilateral nevoid hyperkeratosis of the nipple and areola treated with topical calcitriol. Actas Dermosifiliogr 2008;99:500-1.

10. Foustanos A, Panagiotopoulos K, Ahmad D, Konstantopoulos K. Surgical approach for nevoid hyperkeratosis of the areola. J Cutan Aesthet Surg 2012;5:40-2 